\title{
"SUPERMAN" MENINGKATKAN KEMAMPUAN KEPALA SEKOLAH DALAM MENYUSUN ADMINISTRASI SEKOLAH DI GUGUS 04 KECAMATAN BABAT KABUPATEN LAMONGAN
}

\author{
Muslih'), Yetty Dwi Novia Anggraeni M.2) \\ Institut Pesantren Sunan Drajat Lamongan'1, SDN Manyar Sekaran² \\ Email: muslihalawi@insud.ac.id', yettydwi3@gmail.com
}

Dikirim: 15 Mei 2020 | Direvisi: 21 Juli 2020 | Dipublikasikan: 31 Juli 2020

\begin{abstract}
Abstraksi: Kepala sekolah sebagai manajer tertinggi di satuan pendidikan yang dipimpinnya dituntut untuk memiliki kemampuan (ability) manajerial yang apik, Serta berbagai kompetensi yang melekat pada profesinya. Memiliki kompetensi manajerial dalam penyusunan administrasi sekolah merupakan salah satu yang harus dimiliki kepala sekolah tersebut. berdasarkan pengamatan peneliti didapatkan masih rendahnya kemampuan manajerial kepala sekolah di Gugus 04 Kecamatan Babat Kabupaten Lamongan dalam menyusun administrasi sekolah. Oleh karena itu penelitian ini dilakukan untuk mengetahui bagaimana upaya meningkatkan kemampuan kepala sekolah dalam menyusun administrasi sekolah yang dilakukan oleh pengawas. Penelitian ini merupakan Penelitian Tindakan Kelas (PTK) dengan informan dalam penelitian ini sebanyak 8 orang yakni kepala sekolah dari masing-masing satuan pendidikan di Gugus 04 Kecamatan Babat Kabupaten Lamongan. Kegiatan penelitian meliputi (1) tahap perencanaan (2) pelaksanaan supervisi manajerial secara kelompok (Penataran tingkat lokal)) dalam siklus I dan supervisi manajerial secara individu (percakapan individu)) dalam siklus II (3) menganalisa data (4) pembahasan (5) membuat laporan. Hasil penelitian menunjukkan terjadi peningkatan kemampuan kepala sekolah dalam menyusun administrasi sekolah dibuktikan dengan hasil observasi selama kegiatan berlangsung dan penilaian terhadap administrasi sekolah yang dibuat. Berdasarkan hasil analisis pada masing masing siklus menunjukkan peningkatan kemampuan kepala sekolah dalam menyusun administrasi sekolah yakni: Pada siklus I diperoleh nilai rata-rata terhadap administrasi sekolah yang disusun yaitu 66,25 dan pada siklus II terjadi peningkatan sebesar 15,12\% sehingga nilai-rata administrasi sekolah yang dihasilkan pada siklus II menjadi 81,37. Dengan demikian disimpulkan bahwa melalui kegiatan SUPERMAN dapat meningkatkan kemampuan kepala sekolah dalam menyusun administrasi sekolah di Gugus 04 Kecamatan Babat Kabupaten Lamongan Tahun Pelajaran 2016/2017.
\end{abstract}

Kata kunci: Administrasi; kepemimpian; manajerial; kepala sekolab; Pengavas.

\section{Pendahuluan}

Pada Peratuan Menteri Pendidikan Nasional Nomor 13 Tahun 2007 tentang Standar Kepala Sekolah ditegaskan bahwa salah satu kompetensi yang harus dimiliki seorang kepala sekolah adalah kompetensi manajerial. ${ }^{1}$ Permendiknas tersebut memuat konsekuensi bahwa seorang kepala sekolah sebagai penanggung jawab berlangsungnya pembelajaran yang berkualitas di sekolah harus

\footnotetext{
${ }^{1}$ Pada lampiran permendiknas tersebut dijelaskan terkait kualifikasi dan kompetensi yang harus dimiliki oleh setiap kepala sekolah/madrasah lihat: Peraturan Menteri Pendidkan Nasional Nomor 13 Tahun 2007 Tentang Standar Kepala Sekolah/Madrasah (Jakarta: Kementerian Pendidikan Nasional, 2007), 1-7.
} 
kompeten dalam mengorganisasi dan mengembangkan sumber daya sekolah untuk menciptakan lingkungan belajar yang efektif dan efisien. ${ }^{2}$

Menurut perspektif persekolahan, agar tujuan pendidikan di sekolah dapat tercapai secara efektif dan efisien, maka proses manajemen pendidikan memiliki peranan yang amat vital. Karena bagaimana pun sekolah merupakan suatu sistem yang di dalamnya melibatkan berbagai komponen dan sejumlah kegiatan yang perlu dikelola secara baik dan tertib. Sekolah tanpa didukung proses manajemen yang baik, boleh jadi hanya akan menghasilkan kesemrawutan lajunya organisasi, yang pada gilirannya tujuan pendidikan pun tidak akan pernah tercapai secara semestinya. Dengan demikian, setiap kegiatan pendidikan di sekolah harus memiliki perencanaan yang jelas dan realisitis, pengorganisasian yang efektif dan efisien, pengerahan dan pemotivasian seluruh personil sekolah untuk selalu dapat meningkatkan kualitas kinerjanya, dan pengawasan secara berkelanjutan. ${ }^{3}$

Kepala sekolah memegang peranan penting dalam perkembangan sekolah. dan pegawai sekolah lainnya. Tetapi belum semua kepala sekolah mengerti maksud kepemimpinan, kualitas serta fungsi-fungsi yang harus dijalankan oleh pemimpin pendidikan. Dalam hal ini, kepala sekolah tidak hanya mengatur para guru saja, melainkan juga ketatausahaan sekolah, peserta didik, hubungan sekolah dengan masyarakat dan orang tua peserta didik.

Tercapainya tujuan sekolah sepenuhnya bergantung pada kebijaksanaan yang diterapkan kepala sekolah terhadap seluruh personal sekolah. Dalam melaksanakan fungsinya sebagai pimpinan administrator pendidikan di sekolah, kepala sekolah harus bertanggung jawab terhadap kelancaran pelaksanaan pendidikan dan pengajaran di sekolahnya. Mengingat peran strategis administrasi sekolah bagi keberlangsungan sekolah, maka implikasinya bagi setiap kepala sekolah adalah harus bisa menyusun dan mengelola administrasi sekolah dengan baik, selama ini masih banyak kepala sekolah yang belum bisa menyusun administrasi sekolah dengan baik. Hal ini

\footnotetext{
${ }^{2}$ Faktor kunci keberhasilan suatu sekolah terletak pada bagaimana kepemimpinan kepala sekolah. Sehingga dapat dikatakan bahwa sekolah dikatakan berhasil apabila dipimpin oleh kepala sekolah yang efektif sebagaimana dijelaskan oleh Sobri dalam Bagus Rachmad Saputra, "Keterampilan Manajerial Kepala Sekolah pada Sekolah Umum Berciri Khas Islam", JMSP; Jurnal Manajemen dan Supervisi Pendidikan, Volume 2, Nomor 2, (Maret, 2018)103. Bafadal Juga menegaskan bahwa kepemimpinan sekolah sering dideskripsikan sebagai komponen kunci sebuah sekolah yang baik, sekolah yang efektif, sekolah yang unggul, dan sekolah bertaraf internasional. Baca I. Bafadal, "Penilaian Kinerja Kepala Sekolah sebagai Pemimpin Pembelajaran dalam Rangka Peningkatan Akuntabilitas Sekolah”. Manajemen Pendidikan, Volume 25, Nomor 1, (Maret, 2016), 1-9.

3 Keberhasilan suatu lembaga pendidikan berhubungan erat dengan manajemen yang diterapkan, sehingga tercapainya sebuah tujuan pendidikan tergantung pada sejauh mana keberhasilan suatu lembaga dalam implementasi fungsi-sungsi manajemen dalam seluruh aktivitas dan kinerja organisasi. Baca Hikmat, Manajemen Pendidikan (Bandung: Pustaka Setia, 2009), 14.
} 
dibuktikan dari masih banyaknya kepala sekolah yang tidak membuat administrasi sekolah. Kondisi tersebut juga terjadi di Gugus 04 Kecamatan Babat Kabupaten Lamongan. Berdasarkan hasil supervisi awal didapatkan data sebagai berikut :

Tabel 1

Data Hasil Supervisi Awal Administrasi Sekolah Yang Dibuat Kepala Sekolah

\begin{tabular}{|c|c|c|c|c|c|c|c|c|c|c|c|c|c|c|c|c|}
\hline \multirow{4}{*}{ No. } & \multirow{4}{*}{ Nama Lembaga } & \multicolumn{15}{|c|}{ Jenis Administrasi } \\
\hline & & \multicolumn{3}{|c|}{$\begin{array}{l}\text { Administrasi } \\
\text { Pengajaran }\end{array}$} & \multicolumn{3}{|c|}{$\begin{array}{l}\text { Administrasi } \\
\text { Kemuridan }\end{array}$} & \multicolumn{3}{|c|}{$\begin{array}{l}\text { Administrasi } \\
\text { Kepegawaian }\end{array}$} & \multicolumn{3}{|c|}{$\begin{array}{c}\text { Administrasi } \\
\text { Keuangan }\end{array}$} & \multicolumn{3}{|c|}{$\begin{array}{l}\text { Administrasi } \\
\text { Perlengkapan }\end{array}$} \\
\hline & & \multicolumn{2}{|c|}{ Ada } & \multirow{2}{*}{$\begin{array}{l}\text { Tidak } \\
\text { Ada }\end{array}$} & \multicolumn{2}{|c|}{ Ada } & \multirow{2}{*}{$\begin{array}{l}\text { Tidak } \\
\text { Ada }\end{array}$} & \multirow{2}{*}{$\begin{array}{c}\text { Ada } \\
\text { L }\end{array}$} & \multirow[b]{2}{*}{ TL } & \multirow{2}{*}{$\begin{array}{l}\text { Tidak } \\
\text { Ada }\end{array}$} & \multicolumn{2}{|c|}{ Ada } & \multirow{2}{*}{$\begin{array}{l}\text { Tidak } \\
\text { Ada }\end{array}$} & \multicolumn{2}{|c|}{ Ada } & \multirow{2}{*}{$\begin{array}{l}\text { Tidak } \\
\text { Ada }\end{array}$} \\
\hline & & $\mathrm{L}$ & TL & & $\mathrm{L}$ & TL & & & & & $\mathrm{T}$ & TL & & $\mathrm{L}$ & TL & \\
\hline 1. & SDN Moro pelang & & $\sqrt{ }$ & & & & $\sqrt{ }$ & & $\sqrt{ }$ & & & $\sqrt{ }$ & & & $\sqrt{ }$ & \\
\hline 2. & SDN Tritunggal I & & & $\sqrt{ }$ & & & $\sqrt{ }$ & & & $\sqrt{ }$ & & $\sqrt{ }$ & & & & $\sqrt{ }$ \\
\hline 5. & SDN Keyongan & & & $\sqrt{ }$ & & & $\sqrt{ }$ & & $\sqrt{ }$ & & & $\sqrt{ }$ & & & & $\sqrt{ }$ \\
\hline 6. & SDN Sambangan & & & $\sqrt{ }$ & & & $\sqrt{ }$ & & & $\sqrt{ }$ & & & $\sqrt{ }$ & & & $\sqrt{ }$ \\
\hline 7. & SDN Bulumargi & & & $\sqrt{ }$ & & & $\sqrt{ }$ & & & $\sqrt{ }$ & & $\sqrt{ }$ & & & & $\sqrt{ }$ \\
\hline 8. & SDN Kepoh & & & $\sqrt{ }$ & & & $\sqrt{ }$ & & & $\sqrt{ }$ & & $\sqrt{ }$ & & & & $\sqrt{ }$ \\
\hline
\end{tabular}

Berdasarkan data pada tabel di atas, menunjukkan bahwa kepala sekolah di Gugus 04 Kecamatan Babat masih banyak yang belum bisa menyusun dan mengelola administrasi sekolah dengan baik. Hal ini disebabkan karena, sebagian besar kepala sekolah di gugus 04 Kec. Babat adalah kepala sekolah baru dan belum memiliki pengalaman dalam menyusun administrasi sekolah. Selain itu kurangnya informasi yang diterima karena mereka baru diangkat menjadi kepala sekolah dimana sebelumnya menjabat sebagai guru.

Sehubungan dengan permasalahan tersebut, maka dipandang perlu adanya sebuah solusi untuk meningkatkan kemampuan kepala sekolah dalam melaksanakan tugasnya selaku administrator di bidang akademik di sekolah. Diantara solusi yang dimaksud yaitu kegiatan "SUPERMAN". SUPERMAN adalah akronim dari supervisi manajerial. Supervisi manajerial bagi kepala sekolah di Gugus 04 Kecamatan Babat. Kabupaten Lamongan dilakukan melalui kegiatan supervisi kelompok dan individual. Melalui program tersebut diharapkan kemampuan kepala sekolah dalam menyusun administrasi sekolah dapat meningkat dengan baik.

\section{Kerangka Teori}

\section{Tinjauan Tentang Kepala Sekolah}

Suharsiami Arikunto mendefinisikan kepala sekolah sebagai pemilik, karena kepala sekolah sangat paham dengan kehidupan sekolah sehari-hari. ${ }^{4}$ Seorang kepala sekolah menduduki

\footnotetext{
${ }^{4}$ Suharsimi Arikunto, Dasar-Dasar Evaluasi Pendidikan (Jakarta: Bina Aksara, 2001), 86.
} 
jabatannya karena ditetapkan dan diangkat oleh atasan atau yayasan, tetapi untuk menjalankan tugasnya dengan baik dan lancar, seorang kepala sekolah perlu diterima oleh guru-guru yang dipimpinnya. Sedangkan menurut Wahjosumidjo kepala sekolah adalah seorang tenaga profesional guru yang diberi tugas untuk memimpin suatu sekolah dimana sekolah tersebut menjadi tempat proses belajar mengajar dan terjadi interaksi antara guru yang memberi pelajaran dengan murid yang menerima pelajaran. ${ }^{5}$

Kepala sekolah adalah guru yang mendapat tugas tambahan sebagai kepala sekolah. Meskipun sebagai guru yang mendapat tugas tambahan, kepala sekolah merupakan orang yang paling betanggung jawab terhadap aplikasi prinsip-prinsip administrasi pendidikan yang inovatif di sekolah. Sebagai orang yang mendapat tugas tambahan berarti tugas pokok kepala sekolah tersebut adalah guru yaitu sebagai tenaga pengajar dan pendidik, di sini berarti dalam suatu sekolah seorang kepala sekolah harus mempunyai tugas sebagai seorang guru yang melaksanakan atau memberikan pelajaran atau mengajar bidang studi tertentu atau memberikan bimbingan. Berarti kepala sekolah menduduki dua fungsi yaitu sebagai tenaga kependidikan dan tenaga pendidik. ${ }^{6}$

Pengangkatan kepala sekolah didasarkan atas peraturan yang berlaku. Hal ini diatur dalam Peraturan Menteri Pendidikan Nasional RI No. 28 Tahun 2010 tentang Pengangkatan Kepala Sekolah, sebagai berikut:

1) Pengangkatan kepala sekolah dilakukan melalui penilaian akseptabilitas oleh tim pertimbangan pengangkatan kepala sekolah.

2) Tim pertimbangan pengangkatan kepala sekolah/madrasah ditetapkan oleh Pemerintah, pemerintah provinsi, pemerintah kabupaten/kota, atau penyelenggara sekolah/madrasah yang dilaksanakan oleh masyarakat sesuai dengan kewenangannya.

3) Tim pertimbangan melibatkan unsur pengawas sekolah/madrasah dan dewan pendidikan.

4) Berdasarkan rekomendasi tim pertimbangan pengangkatan kepala sekolah/madrasah, Pemerintah, pemerintah provinsi, pemerintah kabupaten/kota, atau penyelenggara sekolah/madrasah sesuai dengan kewenangannya mengangkat guru menjadi kepala sekolah/madrasah sebagai tugas tambahan.

5) Guru yang diberi tugas tambahan sebagai kepala sekolah/madrasah mendapatkan tunjangan sesuai dengan peraturan perundang-undangan.

Kepala sekolah berkewajiban untuk selalu mengadakan pembinaan yang berarti berusaha agar pengelolaan, penilaian, bimbingan, pengawasan, dan pengembangan pendidikan dapat dilaksanakan dengan lebih baik. ${ }^{8}$ Sedangkan tugas pokok dan fungsi kepala sekolah dalam Buku Kerja Kepala Sekolah yaitu meliputi merencanakan program,melaksanakan rencana kerja, melakukan supervisi dan evaluasi, melaksanakan kepemimpinan sekolah, serta melaksanakan sistem informasi sekolah.

\footnotetext{
${ }^{5}$ Wahjosumidjo, Kepemimpinan Kepala Sekolah. (Jakarta: PT Raja Grafindo Persada, 2003), 83.

${ }^{6}$ Ibid.

7 Peraturan Menteri Pendidikan Nasional Republik Indonesia Nomor 28 Tabun 2010 Tentang Pengangkatan Kepala Sekolah (Jakarta: Kementerian Pendidikan Nasional, 2010), 6-7

${ }^{8}$ Wahjosumidjo, Kepemimpinan..., 203.
} 
Berdasarkan penjelasan di atas, maka dapat disimpulkan bahwa kepala sekolah adalah seorang guru yang diangkat dan ditetapkan baik oleh Departemen Pendidikan dan Kebudayaan ataupun Yayasan secara formal untuk menjadi pemimpin sekolah yang bertugas memimpin dan menjalankan tugas pokok dan fungsinya dalam melaksanakan fungsi-fungsi sekolah sebagaimana visi dan tujuan

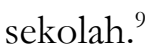

\section{Macam-Macam Kompetensi Kepala Sekolah}

Peraturan Menteri Pendidikan Nasional Republik Indonesia Nomor 13 Tahun 2007 tentang Standar Kepala Sekolah/Madrasah menyebutkan bahwa, kepala sekolah memiliki lima kompetensi yaitu kepribadian, manajerial, kewirausahaan, supervisi, dan sosial. Secara rinci kompetensikompetensi tersebut dapat dijabarkan menjadi beberapa kompetensi dasar sebagai berikut:

1. Kompetensi kepribadian, meliputi:
a. Berakhlak mulia, mengembangkan budaya dan akhlak mulia, menjadi
b. teladan akhlak mulia bagi komunitas di sekolah.
c. Memiliki integritas kepribadian sebagai pemimpin
d. Memiliki keinginan yang kuat dalam pengembangan diri sebagai kepala sekolah
e. Bersikap terbuka dalam melaksanakan tugas pokok dan fungsi
f. Mengendalikan diri dalam menghadapi masalah dalam pekerjaan sebagai kepala sekolah.
g. Memiliki bakat dan minat jabatan sebagai pemimpin pendidikan

2. Kompetensi Manajerial, Meliputi:

a. Adusif dan inovatif bagi pembelajaran peserta didik

b. Mengelola guru dan staf dalam rangka pendayagunaan sumber daya manusia yang optimal

c. Mengelola sarana dan prasarana sekolah dalam rangka pendayagunaan sumber daya sekolah

d. Mengelola hubungan dengan masyarakat dalam rangka pencarian dukungan ide, sumber belajar, dan pembiayaan sekolah

e. Mengelola peserta didik dalam rangka penerimaan peserta didik baru, penempatan, dan pengembangan kapasitas peserta didik

f. Mengelola pengembangan kurikulum dan kegiatan pembelajaran sesuai arah dan tujuan pendidikan nasional

g. Mengelola keuangan sekolah sesuai dengan prinsip pengelolaan yang akuntabel, transparan, dan efisien

h. Mengelola ketatausahaan sekolah dalam mendukung penyusunan program dan pengambilan keputusan

\footnotetext{
9 Pusat Pengembangan Tenaga Kependidikan Badan PSDMP dan PMP, Buku Kerja Kepala Sekolah (Jakarta: Kementerian Pendidikan Nasional, 2011), 7
} 
i. Memanfaatkan kemampuan teknologi informasi bagi peningkatan pembelajaran dan manajemen sekolah

j. Melakukan monitoring, evaluasi dan pelaporan pelaksanaan program kegiatan sekolah dengan prosedur yang tepat serta merencanakan tindak lanjutnya.

3. Kompetensi Kewirausahaan, Meliputi:

a. Menciptakan inovasi yang berguna bagi pengembangan sekolah.

b. Bekerja keras untuk mencapai keberhasilan sekolah sebagai organisasi pembelajaran yang efektif

c. Memiliki motivasi yang kuat dan sukses dalam melaksanakan tugas pokok dan fungsi sebagai pemimpin sekolah

d. Pantang menyerah dan selalu mencari solusi terbaik dalam menghadapi kendala yang dihadapi sekolah

e. Memiliki naluri kewirausahaan dalam mengelola kegiatan sekolah sebagai sumber belajar peserta didik.

4. Kompetensi Supervisi, Meliputi:

a. Merencanakan program supervisi akademik dalam rangka peningkatan profesionalisme guru

b. Melaksanakan supervisi akademik terhadap guru dengan pendekatan dan teknik supervisi yang tepat

c. Menindaklanjuti hasil supervisi akademik terhadap guru dalam rangka peningkatan profesionalisme guru.

5. Kompetensi Sosial, Meliputi:

a. Bekerjasama dengan pihak lain untuk kepentingan sekolah

b. Berpartisipasi dalam kegiatan sosial kemasyarakatan

c. Memiliki kepekaan sosial terhadap orang atau kelompok lain. ${ }^{10}$

Berdasarkan pendapat di atas dapat disimpulkan bahwa menjadi kepala sekolah harus memiliki standar kompetensi yang telah disyaratkan tersebut, tidak semua orang mampu menjadi kepala sekolah karena tugas sebagai kepala sekolah mengandung konsekuensi yang cukup besar. Kepala sekolah diharapkan mampu meningkatkan profesionalitas kepala sekolah dalam mengatur sekolahnya sehingga menghasilkan sekolah yang bermutu karena keberhasilan sekolah tidak terlepas dari kinerja kepala sekolah sendiri dalam memimpin yang nantinya akan memberikan pembaharuan bagi sekolahnya

10 Peraturan Menteri Pendidikan Nasional Nomor 13 Tabun 2007 Tentang Standar Kepala Sekolab/Madrasah (Jakarta: Kemendiknas, 2007), 6-7. Baca juga dalam Sohiron, Administrasi dan Supervisi Pendidikan (Pekan Baru, Kreasi Edukasi, 2015), 151-160. 
Menurut E. Mulyasa kepala sekolah mempunyai 7 fungsi utama, antara lain:
a. Kepala sekolah sebagai educator (pendidik)
b. Kepala sekolah sebagai manajer
c. Kepala sekolah sebagai administrator
d. Kepala sekolah sebagai supervisor
e. Kepala sekolah sebagai leader
f. Kepala sekolah sebagai inovator
g. Kepala sekolah sebagai motivator ${ }^{11}$

\section{Kepala Sekolah Sebagai Administrator}

Kepala sekolah sebagai administrator bermakna kepala sekolah sebagai insan yang mengatur pelaksanaan sistem administrasi pendidikan. Kepala sekolah sebagai administrator bertanggung jawab terhadap kelancaran pelaksanaan pendidikan dan pengajaran di sekolahnya. Ia selalu berusaha agar segala sesuatu di sekolahnya berjalan lancar.

Hal tersebut mencakup seluruh kegiatan sekolah, seperti; proses belajar-mengajar, kesiswaan, personalia, sarana prasarana, ketatausahaan dan keuangan serta mengatur hubungan sekolah dengan masyarakat. Selain itu juga, kepala sekolah bertanggung jawab terhadap keadaan lingkungan sekolahnya.

Menurut Dirawat, tugas dan tanggungjawab kepala sekolah dapat digolongkan menjadi dua bidang, yaitu tugas kepala sekolah dalam bidang administrasi dan tugas kepala dalam bidang supervisi. Tugas kepala sekolah dalam bidang admnistrasi dijabarkan sebagai berikut :

a. Pengelolaan pengajaran

Pengelolaan pengajaran ini merupakan dasar kegiatan dalam melaksanakan tugas pokok.

b. Pengelolaan kepegawaian

Termasuk dalam bidang ini yaitu menyelenggarakan urusan-urusan yang berhubungan dengan penyeleksian, pengangkatan kenaikan pangkat, cuti, perpindahan dan pemberhentian anggota staf sekolah, pembagian tugas-tugas di kalangan anggota staf sekolah, masalah jaminan kesehatan dan ekonomi, penciptaan hubungan kerja yang tepat dan menyenangkan, masalah penerapan kode etik jabatan.

c. Pengelolaan kemuridan

Dalam bidang ini kegiatan yang nampak adalah perencanaan dan penyelenggaran murid baru, pembagian murid atas tingkat-tingkat, kelas-kelas atau kelompok-kelompok (grouping),

${ }^{11}$ E. Mulyasa, Menjadi Kepala Sekolah Profesional dalam Konteks menyukseskan MBS dan KBK (Bandung: Remaja Rosdakarya, 2005), 110. 
perpindahan dan keluar masuknya murid-murid (mutasi), penyelenggaraan pelayanan khusus (special services) bagi murid, mengatur penyelenggaraan dan aktivitas pengajaran, penyelenggaran testing dan kegiatan evaluasi, mempersiapkan laporan tentang kemajuan masalah disiplin murid, pengaturan organisasi siswa, masalah absensi, dan sebagainya.

d. Pengelolaan gedung dan halaman

Pengelolaan ini menyangkut usaha-usaha perencanaan dan pengadaan, inventarisasi, pengaturan pemakaian, pemeliharaan, rehabilitasi perlengkapan dan alat-alat material sekolah, keindahan serta kebersihan umum, usaha melengkapi yang berupa antara lain gedung (ruangan sekolah), lapangan tempat bermain, kebun dan halaman sekolah, meubel sekolah, alat-alat pelajaran klasikal dan alat peraga, perpustakaan sekolah, alat-alat permainan dan rekreasi, fasilitas pemeliharaan sekolah, perlengkapan bagi penyelenggaraan khusus, transportasi sekolah, dan alat-alat komunikasi,

e. Pengelolaan keuangan

Dalam bidang ini menyangkut masalah-masalah urusan gaji guru-guru dan staf sekolah, urusan penyelenggaraan otorisasi sekolah, urusan uang sekolah dan uang alat-alat murid-murid, usahausaha penyediaan biaya bagi penyelenggaraan pertemuan dan perayaan serta keramaian.

f. Pengelolaan hubungan sekolah dan masyarakat

Untuk memperoleh simpati dan bantuan dari masyarakat termasuk orang tua murid-murid, dan untuk dapat menciptakan kerjasama antara sekolah, rumah, dan lembaga-lembaga sosial. ${ }^{12}$

Menurut Purwanto, Sebagai syarat mutlak menjadi kepala sekolah yang berkompeten, harus mampu dengan baik melaksanakan fungsi-fungsi administrasi pendidikan, yang meliputi perencanaan, penyusunan organisasi sekolah, pengoordinasian dan pengarahan serta pengelolaan kepegawaian.

a. Membuat Perencanaan

Perencanaan yang perlu dilakukan oleh kepala sekolah, diantaranya adalah menyusun program tahunan sekolah, yang mencakup program pengajaran, kesiswaan, kepegawaian, keuangan, dan penyediaan fasilitas-fasilitas yang diperlukan. Perencanaan ini selanjutnya dituangkan dalam rencana tahunan sekolah yang dijabarkan dalam dua program semester.

b. Menyusun Organisasi Sekolah

Penyusunan organisasi merupakan tanggungjawab kepala sekolah sebagai administrator pendidikan. Sebelumnya ditetapkan, penyusunan organisasi itu sebaiknya dibahas bersamasama dengan seluruh anggota agar hasil yang diperoleh benar-benar merupakan kesepakatan

12 Dirawat, Pengantar Kepemimpinan Pendidikan (Surabaya: Usaha Nasional, 1986), 80. 
bersama. Selain menyusun struktur organisasi, kepala sekolah juga bertugas untuk mendelegasikan tugas-tugas dan wewenang kepada setiap anggota administrasi sekolah sesuai dengan struktur organisasi yang ada.

c. Bertindak Sebagai Koordinator

Kepala sekolah sebagai admnistrator harus mampu mengoordinasikan bawahannya, yang kegiatannya meliputi pengawasan, penilaian, pengarahan dan bimbingan terhadap setiap personal organisasi sekolah. Dalam pelaksanaan pengoordinasian kepala sekolah sebaiknya bekerja sama dengan berbagai bagian dalam organsasi sekolah, seperti wali kelas, tata usaha, bimbingan dan penyuluhan, guru bagian kurikulum dan lain sebagainya.

d. Melaksanakan Pengelolaan Pegawai

Kepala sekolah memiliki kewenangan dalam mengelola kepegawaian dalam organsasi sekolah, diantaranya kepala sekolah dapat mengangkat, mempromosikan, menempatkan atau menerima pegawai baru, baik itu sebagai guru, TU ataupun pembimbing ekstra kurikurer. Dalam pengelolaan kepegawaian, kepala sekolah harus memperhatikan kesinambungan kondisi dan kemampuan pelaksananya, antara: jenis kelamin, bakat, kekuatan fisik, latar belakang pendidikan dll. ${ }^{13}$

\section{Supervisi Manajerial}

Supervisi adalah kegiatan yang dilakukan oleh pengawas satuan pendidikan dalam rangka membantu kepala sekolah, guru dan tenaga kependidikan lainnya guna meningkatkan mutu dan efektivitas penyelenggaraan pendidikan dan pembelajaran. Supervisi ditujukan pada dua aspek yakni: manajerial dan akademik. ${ }^{14}$

Fokus dari objek supervisi manajerial adalah pada pengelolaan dan administrasi sekolah, dalam hal ini sebagai aspek pendukung (supporting) berhasil tidaknya sebuah proses pembelajaran di suatu satuan pendidikan. Di sisi lain supervisi akademik folus pada kegiatan yang akademik, baik berupa kegiatan belajar di kelas maupun diluar kelas.

Sebagaimana uraian di atas, bahwa dalam Buku Panduan Pelaksanaan Tugas Pengawas Sekolah/Madrasah diuraikan pula tentang supervisi manajerial diartikan sebagai supervisi yang berkenaan dengan aspek pengelolaan sekolah yang terkait langsung dengan peningkatan efisiensi

\footnotetext{
13 Ngalim Purwanto, Administrasi dan Supervisi Pendidikan (Jakarta: PT Remaja Rosdakarya, 2010), 15-18. Lebih lengkapnya baca juga Sohiron, Administrasi dan Supervisi Pendidikan... 23-30.

14 Akhmad Sundrajat, "Konsep Supervisi Manajerial" bisa dibaca lebih lengkap pada blog: https:// akhmadsudrajat.wordpress.com/2010/11/20/supervisi-manajerial/ diakses pada 20 April 2016.
} 
dan efektivitas sekolah yang mencakup perencanaan, koordinasi, pelaksanaan, penilaian, pengembangan kompetensi sumberdaya manusia (SDM) kependidikan dan sumberdaya lainnya. ${ }^{15}$

Dalam melaksanakan fungsi supervisi manajerial, pengawas sekolah/madrasah berperan sebagai: (1) kolaborator dan negosiator dalam proses perencanaan, koordinasi, pengembangan manajemen sekolah, (2) asesor dalam mengidentifikasi kelemahan dan menganalisis potensi sekolah, (3) pusat informasi pengembangan mutu sekolah, dan (4) evaluator terhadap pemaknaan hasil pengawasan.

\section{Prinsip, Metode, dan Teknik Supervisi Manajerial}

Beberapa prinsip supervisi manajerial yang tentunya berbeda dengan supervisi akademik, antara lain: 1) Harus menjauhkan diri dari sifat otoriter, seperti ia bertindak sebagai atasan dan kepala Sekolah/guru sebagai bawahan; 2) Supervisi harus mampu menciptakan hubungan kemanusiaan yang harmonis. Hubungan kemanusiaan yang diciptakan harus bersifat terbuka, kesetiakawanan, dan informal; 3) Supervisi harus dilakukan secara berkesinambungan. Supervisi bukan tugas bersifat sambilan yang hanya dilakukan sewaktu-waktu jika ada kesempatan; 4) Supervisi harus demokratis. Supervisor tidak boleh mendominasi pelaksanaan supervisi. Titik tekan supervisi yang demokratis adalah aktif dan kooperatif; 5) Program supervisi harus integral. . Di dalam setiap organisasi pendidikan terdapat bermacam-macam sistem perilaku dengan tujuan sama, yaitu tujuan pendidikan; 6) Supervisi harus komprehensif. Program supervisi harus mencakup keseluruhan aspek, karena hakikatnya suatu aspek pasti terkait dengan aspek lainnya; 7) Supervisi harus konstruktif. Supervisi bukanlah sekali-kali untuk mencari kesalahan-kesalahan kepala Sekolah/ guru; 8) Supervisi harus obyektif. Dalam menyusun, melaksanakan, dan mengevaluasi, keberhasilan program supervisi harus obyektif. Obyektivitas dalam penyusunan program berarti bahwa program supervisi itu harus disusun berdasarkan persoalan dan kebutuhan nyata yang dihadapi Sekolah. ${ }^{16}$

\section{Metode dan Teknik Supervisi Manajerial}

Berikut ini akan diuraikan tentang beberapa metode supervisi manajerial, yaitu: monitoring dan evaluasi, refleksi dan FGD, metode Delphi, dan Workshop.

a. Monitoring

Monitoring adalah suatu kegiatan untuk mengetahui perkembangan pelaksanaan penyelenggaraan Sekolah, apakah sudah sesuai dengan rencana, program, dan/atau standar

\footnotetext{
15 Direktorat Jenderal Peningkatan Mutu Pendidik dan Tenaga Kependidikan Departemen Pendidikan Nasional, Pedoman Pelaksanaan Tugas Guru dan Pengawas (Jakarta: Dirjen PMTK, 2009), 20.

16 Ratu Vina Rohmatika, "Urgensi Supervisi Manajerial Untuk Peningkatan Kinerja Sekolah”, Jurnal Pengembangan Masyarakat Islam, Volume 9, Nomor 1, (Februari 2016), 6-7.
} 
yang telah ditetapkan, serta menemukan hambatan-hambatan yang harus diatasi dalam pelaksanaan program ${ }^{17}$

b. Evaluasi

Kegiatan evaluasi untuk mengetahui sejauhmana kesuksesan pelaksanaan penyelenggaraan sekolah atau sejauhmana keberhasilan yang telah dicapai dalam kurun waktu tertentu. Tujuan evaluasi utamanya adalah untuk (a) mengetahui tingkat keterlaksanaan program; (b) mengetahui keberhasilan program; (c) mendapatkan bahan/masukan dalam perencanaan tahun berikutnya; dan (d) memberikan penilaian (judgement) terhadap Sekolah. ${ }^{18}$

c. Diskusi Kelompok Terfokus/Focused Group Discussion (FGD)

Hasil monitoring yang dilakukan pengawas hendaknya disampaikan secara terbuka kepada pihak Sekolah, terutama kepala Sekolah, komite Sekolah dan guru. Secara bersama-sama pihak Sekolah dapat melakukan refleksi terhadap data yang ada, dan menemukan sendiri faktorfaktor penghambat serta pendukung yang selama ini mereka rasakan. Forum untuk ini dapat berbentuk Focused Group Discussion (FGD), yang melibatkan unsur-unsur stakeholder Sekolah. Diskusi kelompok terfokus ini dapat dilakukan dalam beberapa putaran sesuai dengan kebutuhan. Tujuan FGD adalah untuk menyatukan pandangan stakeholder mengenai realitas kondisi (kekuatan dan kelemahan) Sekolah, serta menentukan langkah-langkah strategis maupun operasional yang akan diambil untuk memajukan Sekolah. Peran pengawas dalam hal ini adalah sebagai fasilitator sekaligus menjadi narasumber apabila diperlukan, untuk memberikan masukan berdasarkan pengetahuan dan pengalamannya. ${ }^{19}$

d. Metode Delphi

Metode Delphi dapat digunakan oleh pengawas dalam membantu pihak Sekolah merumuskan visi, misi dan tujuannya. Sesuai dengan konsep MBS. Dalam merumuskan Rencana Pengembangan Sekolah (RPS) sebuah Sekolah harus memiliki rumusan visi, misi dan tujuan yang jelas dan realistis yang digali dari kondisi Sekolah, peserta didik, potensi daerah, serta pandangan seluruh stakeholder. Metode Delphi dapat disampaikan oleh pengawas kepada kepala Sekolah ketika hendak mengambil keputusan yang melibatkan banyak pihak. ${ }^{20}$

Dalam pelaksanaan supervisi manajerial, pengawas dapat menerapkan teknik supervisi individual dan kelompok. Teknik supervisi individual di sini adalah pelaksanaan supervisi

\footnotetext{
${ }_{17}$ Resi Yulia Wulandari, "Implementasi Supervisi Manajerial Pengawas Sekolah Dalam Meningkatkan Kompetensi Pengelola Perpustakaan”, Manajer Pendidikan, Volume 10, Nomor 2, (Maret 2016), 136

18 Akhmad Sundrajat, "Konsep Supervisi Manajerial" bisa dibaca lebih lengkap pada blog: https:// akhmadsudrajat.wordpress.com/2010/11/20/supervisi-manajerial/ diakses pada 20 April 2016.

19 Akhmad Sundrajat, "Metode Supervisi Manajerial" bisa dibaca lebih lengkap pada blog. https://akhmadsudrajat.wordpress.com/2011/08/13/metode-supervisi-manajerial/ diakses pada 20 April 2016. ${ }^{20}$ Ibid.
} 
yang diberikan kepada kepala sekolah atau personil lainnya yang mempunyai masalah khusus dan bersifat perorangan. Teknik supervisi kelompok adalah satu cara melaksanakan program supervisi yang ditujukan pada dua orang atau lebih. Kepala-kepala sekolah yang diduga, sesuai dengan analisis kebutuhan, memiliki masalah atau kebutuhan atau kelemahan-kelemahan yang sama dikelompokkan atau dikumpulkan menjadi satu/bersama-sama. Kemudian kepada mereka diberikan layanan supervisi sesuai dengan permasalahan atau kebutuhan yang mereka hadapi.

\section{Administrasi Sekolah}

Beberapa administrasi sekolah yang perlu dikuasai oleh kepala sekolah dalam mengelola lembaga pendidikannya, antara lain:

1. Administrasi Pengajaran, meliputi: Buku pemeriksaan persiapan mengajar; Buku penyelesaian kasus di sekolah/madrasah; Jadwal pelaksanaan supervisi kelas; Buku hubungan kemasyarakatan; Buku program bimbingan; Buku pencapaian target dan daya serap kurikulum; Buku kunjungan pengawas ke sekolah/madrasah; Buku agenda; Buku pengaduan, masukan, kritik, dan saran; Buku supervisi kunjungan kelas.

2. Administrasi Kemuridan/Kesiswaan, meliputi: Formulir pendaftaran murid baru; Buku calon murid baru kelas I; Buku murid baru kelas I; Buku klapper; Papan absen harian murid; Papan rekapitulasi absen harian murid; Buku mutasi murid; Buku rekap mutasi murid selama semester; Surat permohonan pindah sekolah/madrasah; Surat keterangan pindah sekolah/madrasah; Pendaftaran masuk sekolah/madrasah; Buku kenaikan kelas; Buku prestasi murid akademik/non akademik.

3. Administrasi Kepegawaian, meliputi: Buku catatan \ penilaian pegawai negeri sipil; Data kepegawaian; Buku diklat/penataran; Buku penghargaan; Buku seminar/lokakarya; Buku cuti pegawai/guru; Buku izin keluar pegawai/guru.

4. Administrasi keuangan, meliputi: Buku kas umum dan buku kas pembantu.

5. Administrasi perlengkapan/barang, meliputi: Buku kartu inventaris barang; Buku keadaan barang inventaris lainnya ${ }^{21}$

\section{Metode Penelitian}

Rancangan penelitian ini menggunakan jenis Penelitian Tindakan Sekolah (PTS). Tahap penelitian tindakan sekolah yang digunakan antara lain; perencanaan (planning); tindakan (acting); observasi (observing) dan refleksi (reflecting), kemudian berlanjut dengan perencanaan ulang (replanning), tindakan, observasi, dan refleksi untuk siklus berikutnya. ${ }^{22}$ Adapun lokasi penelitian ini

\footnotetext{
${ }^{21}$ Lebih lengkapnya baca Dirjen GTK Kemendikbud, Panduan Kerja Tenaga Administrasi Sekolah/Madraasah (Jakarta: Kemdikbud, 2017), 13-18.

${ }^{22}$ Suharsimi Arikunto, Prosedur Penelitian: Suatu Pendekatan Praktik (Jakarta: Rineka Cipta, 2011), 16.
} 
dilaksanakan di Gugus 04 Kecamatan Babat Kabupaten lamongan yang terdiri dari: SDN Moropelang, SDN Kebonagung, SDN Tritunggal I, SDN Tritunggal II, SDN Keyongan, SDN Sambangan, SDN Bulumargi dan SDN Kepoh. Subjek penelitian tindakan sekolah ini adalah Subjek dalam penelitian tindakan sekolah ini adalah Kepala Sekolah SD di Gugus 04 Kecamatan Babat Kabupaten Lamongan. Jumlah peserta yang dijadikan subjek penelitian tindakan sekolah ini adalah sejumlah 8 orang Kepala Sekolah. Pelaksanaan PTS dimulai dengan siklus pertama yang terdiri dari tiga kegiatan yaitu pendampingan, pendampingan melalui diskusi kelompok, dan supervisi menejerial. Berdasarkan hasil refleksi Siklus I peneliti menganalisis data. Jika nilai rata-rata kemampuan kepala sekolah mencapai rata-rata kelompok $70 \%$, maka tindakan cukup hanya pada siklus pertama. Apabila nilai rata-rata kelompok belum mencapai $70 \%$, maka tindakan siklus I dilanjutkan ke siklus selanjutnya.

\section{Paparan Data Temuan Penelitian}

\section{Siklus I}

\section{Perencanaan Tindakan (Planning)}

Beberapa hal yang dilakukan oleh pengawas pada tahap ini antara lain: Sebelum penelitian peneliti terjun ke lapangan untuk melihat kondisi awal administrasi sekolah yang dibuat oleh kepala sekolah; Menyampaikan hasil kondisi awal kepada kepala sekolah se gugus dan menyampaikan rencana tindakan; Penentuan jadwal dan tempat supervisi manajerial secara kelompok lokal; Menyiapkan bahan bahan yang diperlukan dalam menyusun administrasi sekolah dan; Menentukan Format Observasi serta instrumen/format penilaian administrasi sekolah.

\section{Pelaksanaan Tindakan (Action)}

Peneliti melaksanakan tindakan supervisi manajerial secara kelompok (penataran tingkat lokal gugus) mengenai administrasi sekolah dan membuat administrasi sekolah secara berkelompok kelas kemudian dipresentasikan dan didiskusikan. Pelaksanaan tindakan dalam siklus I dilaksanakan dalam tiga pertemuan.

\section{Pertemuan I}

Tindakan yang dilakukan pada pertemuan ini antara lain: Mendiskusikan tentang permasalahan dalam menyusun administrasi kepala sekolah; Penyampaian informasi tentang cara penyusunan administrasi sekolah; serta memberikan contoh model administrasi sekolah; Mengkaji contoh model administrasi sekolah dalam kelompok; Menugaskan kepala sekolah untuk membuat administrasi sekolah di rumah

\section{Pertemuan II}

Tindakan yang dilakukan pada pertemuan ini, antara lain: kepala sekolah mendiskusikan administrasi 
sekolah dalam kelompok; Masing-masing kepala sekolah mempresentasikan hasil administrasi sekolah yang telah disusun; Peneliti dan kepala sekolah yang lain mencermati dan menaggapi presentasi yang dilakukan oleh masing-masing kepala sekolah; dan Kepala Sekolah merevisi administrasi sekolah yang telah dipresentasikan di rumah.

\section{Pertemuan III}

Tindakan yang dilakukan pada pertemuan ini, antara lain: Peneliti menilai hasil administrasi sekolah yang telah direvisi oleh masing-masing kepala sekolah; Peneliti menyampaikan hasil penilaian kepada semua kepala sekolah; Jika hasil nilai administrasi sekolah belum sesuai dengan yang diharapkan maka kepala sekolah merevisi kembali administrasi sekolah sesuai petunjuk yang telah diberikan oleh peneliti.

\section{Target yang diharapkan pada siklus I :}

Pertemuan pertama dihasilkan konsep (format administrasi sekolah), pada pertemuan kedua tersusunnya administrasi sekolah dan pada pertemuan ketiga tersusunnya administrasi sekolah yang optimal yang mana mendeskripsikan kompetensi kepala sekolah dibidang administrasi pendidikan.

\section{Observasi}

Observasi dilakukan oleh peneliti pada saat Kepala Sekolah mendiskusikan administrasi sekolah di pertemuan kedua, baik secara individu maupun kelompok. Pengamatan dilakukan terhadap sikap Kepala Sekolah tentang kesiapan bahan, kerjasama, aktivitas, presentasi dalam mendiskusikan administrasi sekolah yang telah dibuat.

Sedangkan evaluasi dilakukan diakhir pertemuan siklus I dengan menilai administrasi sekolah yang telah disusun dengan menggunakan format evaluai administrasi sekolah (terlampir). Adapun cara melakukan penilaian instrument observasi dan instrumen penilaian administrasi sekolah adalah menggunakan skala Likert dengan lima katagori yaitu : sangat tinggi, tinggi, sedang, rendah dan sangat rendah. Penilaian dilakukan dengan memberikan skor pada kolom yang tersedia dengan ketentuan sebagai berikut: skor 5 = sangat tinggi, skor $4=$ tinggi, skor $3=$ sedang, skor $2=$ rendah, dan skor 1 $=$ sangat rendah. Sehingga skor maksimal adalah $4 \times 5=20$. Untuk mendapatkan nilai digunakan rumus :

$$
\mathrm{N}=\frac{\text { Jumlah skor perolehan }}{\text { Jumlah skor maksimal }} \times 100
$$

Setelah diperoleh nilai, maka nilai tersebut ditransfer ke dalam bentuk kualitatif untuk memberikan komentar bagaimana kualitas sikap kepala sekolah yang diamati dalam menyusun administrasi sekolah dengan kategori sebagai berikut : 
Tabel 2.

Tabel Kategori Sikap

\begin{tabular}{|c|c|l|}
\hline No & Skor & \multicolumn{1}{|c|}{ Kategori Sikap } \\
\hline 1 & $90-100$ & A (Amat baik) \\
\hline 2 & $80-89$ & B (Baik) \\
\hline 3 & $65-79$ & C ( Cukup) \\
\hline 4 & $55-64$ & D ( Kurang) \\
\hline 5 & $0-54$ & E (Amat kurang) \\
\hline
\end{tabular}

Penilaian administrasi sekolah ini kategori/ predikat hasil penilaian yang digunakan adalah:

Tabel 3

Kategori Hasil Penilaian

\begin{tabular}{|c|c|l|}
\hline No & Skor & \multicolumn{1}{|c|}{ Kategori Sikap } \\
\hline 1 & $90-100$ & A (Amat baik) \\
\hline 2 & $80-89$ & B (Baik) \\
\hline 3 & $65-79$ & C ( Cukup) \\
\hline 4 & $55-64$ & D ( Kurang) \\
\hline 5 & $0-54$ & E ( Amat kurang) \\
\hline
\end{tabular}

\section{Refleksi}

Bedasarkan hasil observasi dan evaluasi yang dilakukan selama berlangsungnya kegiatan penyusunan administrasi sekolah dilakukan refleksi. Hasil refleksi ini dijadikan acuan untuk merencanakan penyempurnaan dan perbaikan pada siklus II. Bila kepala sekolah memperoleh skor dalam penilaian administrasi sekolah sama/lebih besar dari 70 maka kepala sekolah tersebut dinyatakan berhasil atau layak. Jika kurang dari 70, maka kepala sekolah tersebut dinyatakan belum berhasil. Kepala sekolah yang belum berhasi diprogramkan untuk mengikuti siklus II.

\section{Siklus II}

\section{Perencanaan}

Peneliti menyampaikan hasil penyusunan administrasi sekolah pada siklus I kepada kepala sekolah dan menginformasikan rencana pelaksanaan tindakan pada siklus II.

\section{Pelaksanaan}

Peneliti memberikan supervisi manajerial secara individu (percakapan individu) dengan harapan masing-masing kepala sekolah mengetahui kelebihan dan kekurangannya tentang administrasi sekolah yang sudah dibuat pada siklus I dengan harapan hasil pada siklus II akan meningkat

\section{Evaluasi}


Evaluasi dilakukan terhadap administrasi sekolah yang telah disusun dengan menggunakan format evaluai administrasi sekolah. Cara melakukan penilaian terhadap hasil administrasi sekolah yang disusun sama dengan siklus I.

\section{Refleksi}

Berdasarkan hasil evaluasi pada akhir pertemuan siklus II dilakukan refleksi. Bila Kepala sekolah memperoleh skor dalam penilaian administrasi sekolah final sama atau lebih besar dari 70, maka Kepala Sekolah tersebut dinyatakan berhasil, jika kurang dari 70 dinyatakan belum berhasil. Kepala Sekolah yang belum berhasil perlu ada pemikiran tindakan selanjutnya.

\section{Pembahasan dan Diskusi Hasil penelitian}

Penelitian ini merupakan penelitian tindakan sekolah (PTS) berupa kegiatan SUPERMAN (supervisi manajerial) melalui dua siklus. Dalam siklus I pemberian tindakan berupa supervisi manajerial secara kelompok (workshop) dan dalam siklus II tindakan berupa supervisi manajerial secara individu (wawancara) terhadap kepala sekolah di SD Gugus 04 kecamatan Babat.

Temuan di lapangan kondisi awal diketahui bahwa beberapa kepala sekolah dasar di Gugus 04kecamatan Babat belum mampu menyusun administrasi sekolah dengan baik dan benar. Masih banyak administrasi sekolah yang tidak dibuat oleh kepala sekolah. Hal ini disebabkan karena 62,5\% kepala sekolah di Gugus 04 Kecamatan Babat adalah kepala sekolah baru dan belum memiliki pengalaman dalam menyusun administrasi sekolah dengan baik. Hal ini disebabkan oleh kurangnya pengalaman dan kurangnya informasi yang diterima karena mereka baru diangkat menjadi kepala sekolah dimana sebelumnya menjabat sebagai guru.

Pada siklus I di pertemuan peneliti mendiskusikan tentang permasalahan yang dihadapi kepala sekolah dalam menyusun administrasi sekolah melalui kelompok. Setelah mengetahui permasalahan yang dihadapi oleh masing-masing kepala sekolah peneliti kemudian menyampaikan informasi tentang cara menyusun administrasi sekolah serta memberikan contoh model administrasi sekolah yang baik dan benar. Setelah itu, masing-masing kelompok mengkaji contoh model administrasi sekolah yang diberikan, kemudian menetapkan format administrasi sekolah yang digunakan. Setelah menyepakati format yang digunakan peneliti menugaskan kepada masing-masing kepala sekolah untuk menyusun administrasi sekolah di rumah. kepala sekolah diberi waktu sebulan untuk mempelajari dan menyusun administrasi sekolah. Administrasi sekolah yang telah dibuat akan didiskusikan pada pertemuan kedua.

Pada pertemuan kedua kepala sekolah dibantu oleh peneliti mendiskusikan administrasi sekolah yang telah dibuat dalam kelompok dengan mempresentasikan hasil administrasi sekolah yang telah disusun. Peneliti dan kepala sekolah yang lain mencermati dan menaggapi presentasi yang dilakukan 
oleh masing-masing kepala sekolah. Kepala Sekolah merevisi administrasi sekolah yang telah dipresentasikan di rumah. Hasil pengamatan/ observasi tentang sikap kepala sekolah dalam menyusun administrasi sekolah pada siklus pertama adalah sebagai berikut:

Tabel 4

Hasil Observasi (Siklus I)

\begin{tabular}{|c|c|c|c|c|c|c|c|c|}
\hline \multirow{2}{*}{ No } & \multirow{2}{*}{ Nama Kepala Sekolah } & \multicolumn{4}{|c|}{ Aspek } & \multirow{2}{*}{ Skor } & \multirow{2}{*}{ Nilai } & \multirow{2}{*}{ Kategori } \\
\hline & & Bahan & Kerjasama & Aktivitas & Presentasi & & & \\
\hline 1 & H. A. Sahudi, S.Pd & 5 & 4 & 4 & 4 & 17 & 85 & B \\
\hline 2 & Nasi'atul Aissiah, S.Pd. & 4 & 4 & 5 & 4 & 17 & 85 & B \\
\hline 3 & Khozin, S. Pd.I & 4 & 4 & 4 & 4 & 16 & 80 & B \\
\hline 4 & H. A.Ghufron, S.Pd.I & 5 & 4 & 4 & 4 & 17 & 85 & B \\
\hline 5 & Sugito, S.Pd & 4 & 4 & 4 & 4 & 16 & 80 & B \\
\hline 6 & Alex Sudrajat, S.Pd & 4 & 4 & 4 & 4 & 16 & 80 & B \\
\hline 7 & Matadji, S.Pd.I & 4 & 4 & 4 & 4 & 16 & 80 & B \\
\hline 8 & Karno, S.Pd & 4 & 3 & 4 & 4 & 15 & 75 & $\mathrm{C}$ \\
\hline \multicolumn{2}{|c|}{ Jumlah } & 34 & 31 & 33 & 32 & 130 & 650 & \\
\hline \multicolumn{2}{|c|}{ Rata-Rata } & 4,25 & 3,87 & 4,12 & 4 & & 81,25 & B \\
\hline
\end{tabular}

Berdasarkan data hasil observasi siklus I terhadap sikap kepala sekolah dalam menyusun administrasi sekolah diperoleh hasil baik dengan rata-rata nilai 81,25. Berdasarkan hasil observasi terlihat bahwa semua kepala sekolah telah membawa administrasi sekolah yang telah dipelajari dan disusun pada pertemuan sebelumnya. Selain itu, Kepala sekolah antusias melaksanakan setiap aktivitas yang diberikan.. Hal ini terlihat dari keaktivan kepala sekolah selama berdiskusi bersama kelompok. Selain itu kepala sekolah juga mampu bekerjasama dengan baik untuk mencari kelebihan dan kekurangan administrasi sekolah yang telah dibuat. Kepala sekolah juga mampu mempresentasikan hasil administrasi sekolah yang telah dibuat dengan baik.

Pada pertemuan ketiga didapatkan hasil penilaian administrasi kepala sekolah pada siklus I, berikut uraian datanya:

Tabel 5

Data Hasil Penilaian Administrasi Sekolah (Siklus I)

\begin{tabular}{|c|l|c|c|}
\hline No. & \multicolumn{1}{|c|}{ Nama Kepala Sekolah } & Nilai & Kategori \\
\hline 1 & H. A. Sahudi, S.Pd & 70 & B \\
\hline 2 & Nasi'atul Aissiah, S.Pd. & 69 & C \\
\hline 3 & Khozin, S.Pd.I & 61 & C \\
\hline 4 & H. A.Ghufron, S.Pd.I & 68 & C \\
\hline 5 & Sugito, S.Pd & 68 & C \\
\hline 6 & Alex Sudrajat, S.Pd & 67 & C \\
\hline 7 & Mataji, S.Pd.I & 66 & C \\
\hline 8 & Karno, S.Pd & 530 & C \\
\hline Jumlah & & 66,25 & C \\
\hline
\end{tabular}


Pada akhir pertemuan siklus pertama peneliti menilai hasil administrasi sekolah yang telah dibuat oleh kepala sekolah. Hasil penilaian terhadap administrasi sekolah yang disusun oleh kepala sekolah diperoleh nilai rata-rata 66,25 dalam katagori cukup. Dengan memperhatikan hasil penilaian pada siklus I peneliti melakukan refleksi terhadap hasil yang diperoleh.

Hambatan-hambatan yang ditemukan pada sikus I seperti efektivitas penyampaian informasiinformasi tentang cara penyusunan administrasi sekolah yang masih bersifat umum dianalisis lagi. Karena masih banyak kepala sekolah mendapat nilai di bawah 70 dalam penilaian administrasi sekolah pada siklus I, maka peneliti merencanakan siklus II untuk meningkatkan hasil penyusunan administrasi pada siklus I agar sesuai dengan standar yang telah ditetapkan yaitu semua kepala sekolah mendapat nilai 70 atau lebih.

\section{Siklus II}

Pada siklus II kegiatan yang dilakukan adalah mendiskusikan hambatan-hambatan yang dihadapi dalam penyusunan administrasi sekolah di siklus pertama. Menyampaikan hasil siklus I kepada Kepala sekolah. Kekurangan hasil pada siklus I ini ditindaklanjuti peneliti dengan merencanakan supervisi manajerial secara individual (percakapan pribadi) dengan jalan langsung ke sekolah-sekolah se gugus untuk membina secara individu membahas administrasi sekolah yang telah disusun dan diisi oleh kepala sekolah. Hasil supervisi manajerial dipadukan dengan juknis yang ada agar kepala sekolah mengetahui kekurangsempurnaan administrasi sekolah yang sudah dibuatnya Peneliti membantu menyempurnakan dan memecahkan kesulitan kepala sekolah. Hasil penilaian terhadap administrasi sekolah yang telah disusun oleh Kepala Sekolah adalah sebagai berikut :

Tabel 6

Data Hasil Penilaian Administrasi Sekolah (Siklus II)

\begin{tabular}{|c|l|c|c|}
\hline No. & \multicolumn{1}{|c|}{ Nama Kepala Sekolah } & Nilai & Kategori \\
\hline 1 & H. A. Sahudi, S.Pd & 85 & B \\
\hline 2 & Nasi'atul Aissiah, S.Pd. & 84 & B \\
\hline 3 & Khozin, S.Pd.I & 76 & B \\
\hline 4 & H. A.Ghufron, S.Pd.I & 87 & B \\
\hline 5 & Sugito, S.Pd & 83 & B \\
\hline 6 & Alex Sudrajat, S.Pd & 82 & B \\
\hline 7 & Mataji, S.Pd.I & 75 & B \\
\hline 8 & Karno, S.Pd & 651 & B \\
\hline Jumlah & & 81,37 & B \\
\hline Rata-Rata & & \\
\hline
\end{tabular}


Data yang diperoleh dari hasil penilaian terhadap penilaian administrasi sekolah yang disusun oleh kepala sekolah diperoleh rata-rata 81,37 dengan katagori baik. Memperhatikan hasil pada siklus II melakukan refleksi terhadap hasil yang diperoleh peneliti pada siklus II ini sudah ada peningkatan kemampuan kepala sekolah dalam menyusun administrasi sekolah.

Berdasarkan hasil penelitian dapat diketahui bahwa melalui kegiatan SUPERMAN (Supervisi Manajerial) Kepala sekolah SD di Gugus 04 Kecamatan Babat Kabupaten Lamongan mampu menyusun administrasi sekolah yang sesuai dengan kreteria yang ditentukan. Yang pada awalnya sekolah tidak memiliki administrasi sekolah dan tidak memiliki perencanaan, jadi setelah dibimbing melalui kegiatan SUPERMAN menghasilkan administrasi sekolah yang baik dan benar. Pada siklus I diperoleh nilai rata terhadap administrasi sekolah yang disusun yaitu 66,25 dan pada siklus II terjadi peningkatan sebesar 15,12 sehingga nilai rata rata administrasi sekolah yang dihasilkan pada siklus II adalah 81,37 .

Pelaksanaan pembinaan oleh pengawas sekolah dengan kegiatan SUPERMAN (supervisi manajerial) berlangsung dengan suasana kekeluargaan, kebersamaan, keterbukaan dan keteladanan. Disamping itu hubungan antara pengawas dengan kepala sekolah bersifat obyektif serta didasari hubungan manusiawi yang sehat. Selanjutnya interaksi antara pengawas dilandasi oleh nilai nilai tersebut melahirkan tanggungjawab bersama dalam upaya perbaikan pengelolaan sekolah. Disamping pembinaan secara kelompok yakni melalui workshop dan pembinaan secara individu yaitu berdasarkan informasi kepala sekolah cara ini sangat efektif sehingga Kepala Sekolah bisa memiliki administrasi sekolah yang komprehensif.

\section{Kesimpulan}

Pertama, dengan diterapkannya Manajemen Berbasis Sekolah yang merupakan salah satu bentuk pengelolaan sekolah yang menempatkan sekolah sebagai pemegang peran utama pengelolaan sekolah dalam upaya peningkatan mutu. Maka setiap sekolah perlu menyusun administrasi sekolah secara baik. dengan dilaksanakan kegiatan SUPERMAN (supervisi manajaerial) secara kelompok dan individu serta kekeluargaan. Kepala Sekolah merasa terbantu dalam melaksanakan tugas-tugasnya selaku kepala sekolah khususnya dalam penyusunan perencanaan sekolah. Disamping hal tersebut sekolah memiliki administrasi sekolah yang bertujuan untuk : (1) agar tujuan yang telah ditetapkan dapat dicapai , (2) mendukung koordinasi antar pelaku sekolah, (3) adanya keterkaitan dan konsistensi antara perencanaan penganggaran, pelaksanaan dan pengawasan, (4) mengoptimalkan partisipasi masyarakat, (5) penggunaan sumberdaya secara efisien, efektif dan berkelanjutan.

Kedua, dengan kegiatan SUPERMAN (supervisi manajaerial) kemampuan Kepala Sekolah dapat ditingkatkan utamanya kemampuan menyusun administrasi sekolah yang sebelumnya mereka 
beranggapan bahwa administrasi sekolah adalah sebagai pelengkap belaka. Hal ini dibuktikan dari tidak membuat kemudian pada siklus I kepala sekolah memperoleh nilai 66,25 dan meningkat menjadi 81,37 pada siklus II

\section{Daftar Kepustakaan}

Arikunto, Suharsimi. Dasar-Dasar Evaluasi Pendidikan. Jakarta: Bina Aksara, 2001. Prosedur Penelitian: Suatu Pendekatan Praktik. Jakarta: Rineka Cipta, 2011.

Bafadal, I. "Penilaian Kinerja Kepala Sekolah sebagai Pemimpin Pembelajaran dalam Rangka Peningkatan Akuntabilitas Sekolah". Manajemen Pendidikan, Volume 25, Nomor 1, (Maret, 2016), 1-9.

Dirawat. Pengantar Kepemimpinan Pendidikan. Surabaya: Usaha Nasional, 1986.

Direktorat Jenderal Peningkatan Mutu Pendidik dan Tenaga Kependidikan Departemen Pendidikan Nasional, Pedoman Pelaksanaan Tugas Guru dan Pengawas. Jakarta: Dirjen PMTK, 2009.

Dirjen GTK Kemendikbud, Panduan Kerja Tenaga Administrasi Sekolah/Madraasah. Jakarta: Kemdikbud, 2017.

Hikmat. Manajemen Pendidikan. Bandung: Pustaka Setia, 2009.

Mulyasa, E. Menjadi Kepala Sekolah Profesional dalam Konteks menyukseskan MBS dan KBK. Bandung: Remaja Rosdakarya, 2005.

Peraturan Menteri Pendidkan Nasional Nomor 13 Tabun 2007 Tentang Standar Kepala Sekolab/Madrasah. Jakarta: Kementerian Pendidikan Nasional, 2007.

Peraturan Menteri Pendidikan Nasional Republik Indonesia Nomor 28 Tabun 2010 Tentang Pengangkatan Kepala Sekolah. Jakarta: Kementerian Pendidikan Nasional, 2010.

Purwanto, Ngalim. Administrasi dan Supervisi Pendidikan. Jakarta: PT Remaja Rosdakarya, 2010.

Pusat Pengembangan Tenaga Kependidikan Badan PSDMP dan PMP, Buku Kerja Kepala Sekolah. Jakarta: Kementerian Pendidikan Nasional, 2011.

Rohmatika, Ratu Vina. "Urgensi Supervisi Manajerial Untuk Peningkatan Kinerja Sekolah", Jurnal Pengembangan Masyarakat Islam, Volume 9, Nomor 1, (Februari 2016), 6-7.

Saputra, Bagus Rachmad. "Keterampilan Manajerial Kepala Sekolah pada Sekolah Umum Berciri Khas Islam", JMSP; Jurnal Manajemen dan Supervisi Pendidikan, Volume 2, Nomor 2, (Maret, 2018), 103.

Sundrajat, Akhmad. "Konsep Supervisi Manajerial” bisa dibaca lebih lengkap pada blog: https:// akhmadsudrajat.wordpress.com/2010/11/20/supervisi-manajerial/ diakses pada 20 April 2016.

"Metode Supervisi Manajerial" bisa dibaca lebih lengkap pada blog: https://akhmadsudrajat.wordpress.com/2011/08/13/metode-supervisi-manajerial/ diakses pada 20 April 2016.

Wahjosumidjo. Kepemimpinan Kepala Sekolah. Jakarta: PT Raja Grafindo Persada, 2003.

Sohiron, Administrasi dan Supervisi Pendidikan. Pekan Baru, Kreasi Edukasi, 2015.

Wulandari, Resi Yulia "Implementasi Supervisi Manajerial Pengawas Sekolah Dalam Meningkatkan Kompetensi Pengelola Perpustakaan", Manajer Pendidikan, Volume 10, Nomor 2, (Maret 2016), 136 